\title{
Quality and safety of potable water from private water wells around Warsaw
}

\author{
J. Bertrandt, A. Kłos, R. Łakomy and E. Stężycka \\ Military Institute of Hygiene and Epidemiology, 4Kozielska St., 01-163 Warsaw, Poland
}

Over $90 \%$ of private water consumers in the environs of Warsaw use water supplied by the municipal water supply system. Part of households placed around Warsaw is supplied with water form their own water intakes. Most often there are water wells drilled up to 8-30 meters down. According to the Central Statistical Office data about $40 \%$ of examined groundwater in Poland doesn't meet physicochemical requirements for potable water ${ }^{(1)}$. Knowing about it, users of private water wells commission water quality tests in their own wells. Carrying out quality tests of water from private wells is not obligatory and owners have to pay for such tests themselves.

Quality tests of water from 39 water wells in Warsaw and its environs were carried out in 2010-2012. Nitrates, nitrites, iron, manganese and ammonium ion were spectrophotometrically determined using the HACH's Drell-4000 apparatus. To determine turbidity of water the HACH's 100 NIS turbiditimeter was used. Hardness, chlorides and oxidizability were determined by titration. Colour was determined by visual method comparing samples with platinum standard solutions. Results are presented in table.

\begin{tabular}{|c|c|c|c|c|c|}
\hline \multirow[b]{2}{*}{ Parameter } & \multirow[b]{2}{*}{ Unit } & \multirow[b]{2}{*}{ Range } & \multirow{2}{*}{$\begin{array}{l}\% \text { of samples exceeding } \\
\text { acceptable content }\end{array}$} & \multicolumn{2}{|c|}{ Acceptable value } \\
\hline & & & & Poland & WHO \\
\hline Apparent colour & $\mathrm{mg} / \mathrm{l} \mathrm{Pt}$ & $3-70$ & 25,71 & Acceptable & 15 \\
\hline Turbidity & NTU & $0,1-41$ & 48,57 & 1 & 5 \\
\hline Ammonium ion & $\mathrm{mg} / \mathrm{l}$ & $0,01-2,95$ & 25,71 & 0,50 & 1,5 \\
\hline Nitrates & $\mathrm{mg} / \mathrm{l}$ & $0,5-73$ & 5,71 & 50 & 50 \\
\hline Nitrites & $\mathrm{mg} / \mathrm{l}$ & $0,003-4,08$ & 8,57 & 0,50 & 0,2 \\
\hline Iron & $\mu \mathrm{g} / 1$ & $10-6480$ & 48,57 & 200 & 300 \\
\hline Manganese & $\mu \mathrm{g} / 1$ & 5-2556 & 68,57 & 50 & 100 \\
\hline Oxidizability & $\mathrm{mg} \mathrm{O} 2 / 1$ & $0,5-7,3$ & 8,57 & 5 & - \\
\hline $\mathrm{PH}$ & - & $6,00-8,3$ & 2,85 & $6,5-9,5$ & $6,5-8,0$ \\
\hline Hardness & $\mathrm{mg} / \mathrm{l} \mathrm{CaCO} 3$ & $<10-400$ & 14,2 & $60-500$ & 500 \\
\hline Chlorides & $\mathrm{mg} / \mathrm{l}$ & $<5-235$ & 0 & 250 & 250 \\
\hline
\end{tabular}

Exceeding of ammonia concentration in potable water shouldn't have any effect on health (as far as this ammonia is not of sewage origin). However exceeded ammonia content may unfavourably influence on taste and smell of water as well as may be a cause of nitrites formation. The most common reason of limits exceeding was manganese $(68 \%)$, iron $(48 \%)$, turbidity $(48 \%)$ and ammonia $(26 \%)$. According to WHO recommendations ${ }^{(2)}$ manganese content in potable water amounts to $400 \mathrm{mg} / \mathrm{l}$. Nonetheless, Polish norm is lower and amounts to $50 \mathrm{mg} / \mathrm{l}$ because consumers don't accept occurrence of undesired sediment and coloration of sanitations.

This work was supported by The National Centre for Research and Development(Poland) - Grant PBS1/A7/6/2012.

1. Regulation of the Minister of Health of 29 March 2007 on the quality of water intended for human consumption, OJ 2007 No. 61 , item. 417.

2. Guidelines for drinking-water quality, Vol. 1, Recommendations, Warsaw 1998, 53, 66-67, 218. 